\title{
Effect of Dose Biochar Bamboo, Compost, and Phonska on Growth of Maize (Zea mays L.) in Dryland
}

\author{
Yohanes Parlindungan Situmeang\#, I Made Adnyana ${ }^{*}$, I Nengah Netera Subadiyasa ${ }^{*}$, I Nyoman Merit ${ }^{*}$ \\ ${ }^{\#}$ Faculty of Agriculture, Warmadewa University, Denpasar, Bali, Indonesia \\ E-mail: ypsitumeang63@gmail.com
}

* Postgraduate Agricultural Science Program, Udayana University, Denpasar-Bali, Indonesia

\begin{abstract}
The purpose of this study was to determine the effect of treatment of various doses of biochar level bamboo, compost, and phonska on hybrid corn plant growth bisi-2 super in dry land. The design used in this study is a randomized block design (RAK) with a pattern of nested experiments. Factors treatment consists of 3 types of materials to improve soil quality, that biochar bamboo, organic compost fertilizer and inorganic fertilizer dose phonska with 4 levels and a control for comparison. The results showed that the treatment of the type of fertilizer had no significant effect on all the variables observed. While the dosage of biochar bamboo gives highly significant effect on plant height, number of leaves and total leaf area per plant. The highest result of variable plant height, number of leaves and total leaf area per plant corn obtained at treatment dose of 5-10 tons/ha biochar bamboo, 10-20 tons/ha of compost and $300 \mathrm{~kg} / \mathrm{ha}$ phonska. From the results of the regression analysis obtained optimum doses of biochar bamboo 10.93 tonnes/ha with maximum plant height of $244.11 \mathrm{~cm}$, the optimum dose of compost 19.54 tonnes/ha with maximum plant height of $247.89 \mathrm{~cm}$, and the optimum dose phonska $308.11 \mathrm{~kg} / \mathrm{ha}$ with a plant height of $246.32 \mathrm{~cm}$.
\end{abstract}

Keywords — biochar bamboo; compost; phonska; maize; dryland

\section{INTRODUCTION}

Dryland farming in Bali province has the opportunity and the challenge to develop into productive land for crops, especially corn crops that can adapt to drought. The chances of developing dry land to plant corn in Bali can be seen from land and productivity potentials. Agricultural land in Bali 563,666 ha, about 126,713 ha $(22.48 \%)$ is dry land [4]. Productivity or average production of maize in Bali 2.94 tons/ha [5] was still very low when compared with the national maize production of 4.89 tons/ha. The low yield of corn can be improved with the use of hybrid varieties Bisi-2, which has the potential yield may reach 9.0 to 13.0 tons / ha dry seed [11].

Dry soil conditions are generally characterized by poor soil structure, C-organic content is very low, nutrient and water retention ability is low. Improvement in soil quality dry land can be done with the use of biochar. Biochar is made of the result of incomplete combustion (pyrolysis) of agricultural waste which is difficult to be decomposed. Incomplete combustion is done by using a tool or pirolisator combustion temperature of $250-350^{\circ} \mathrm{C}$, for 2.0 to 3.5 hours, in order to obtain charcoal containing high carbon and can be applied as a soil amendment [3].
Waste bamboo has a great potential to be used as raw material for making biochar. Biochar known biological charcoal is a solid material that is formed from the carbonization of biomass. Biochar is added to soil can improve soil functions and reduce emissions from biomass that naturally breaks down into greenhouse gases. Biochar can sequester carbon, produce good fiber and highly porous charcoal that helps soil hold nutrients and water, and improve food safety [6].

Biochar is charcoal black biomass results from the heating process in the state of limited oxygen or no oxygen. Biochar is an organic material that has stable properties can be used as a soil amendment on dry land. Biochar can improve soil fertility and were able to recover degraded soil quality ([2], [9]). International attention to the use of biochar as an agricultural soil amendment evolved from the observation in the Brazilian Amazon [8].

Biochar is added to soil can improve the growth and yield as well as the potential to revolutionize the concept of land management. Single application of biochar can provide beneficial effects during the growing season in some farms. Biochar as soil difficult to decompose is one alternative to accelerate the improvement of soil physical properties and overall quality dry land [10]. Biochar can improve soil quality in various ways, including increased porosity, heavy 
volume, and the availability of water, increasing the $\mathrm{pH}, \mathrm{C}$ organic, phosphorus, potassium, and cation exchange capacity, reduced nitrogen leaching and increase the activity of microbial populations. The influence of biochar bamboo in the ground of the nature of the biological, chemical and physical properties are very complex, so it is necessary to study biochar to obtain growth and crop production significantly increased.

The process of decomposition of biochar as compared with composted manure and phonska in the soil to supply nutrients to plants is very different. Biochar is very difficult to decompose and organic fertilizers such as compost slowly decomposes in the soil, while the provision of inorganic fertilizers such as NPK phonska more quickly available to plants. In a balanced utilization of biochar, compost organic and inorganic fertilizers NPK phonska can provide better conditions for growth and ensure adequate nutrients for plants and can reduce the use of synthetic fertilizers and maintaining soil fertility in a sustainable agriculture.

This study aims to determine the effect of treatment doses of biochar bamboo, compost, and phonska on the growth of maize crops in dry land. The hypothesis is treated with various dose level in various types of fertilizer will be obtained the highest results.

\section{METHODS}

This research was conducted in a poly bag (pot) at Greenhouse Garden Research Faculty of Agriculture, University of Udayana, Denpasar, Bali. The experiments carried out from August to October 2015. The materials used are hybrid corn seed varieties Bisi-2, biochar made from bamboo processed waste pyrolysis, compost "Simantri" made from raw cow manure, Phonska $(15 \%$ N, $15 \%$ P, $15 \%$ $\mathrm{K}$ ), and the soil surface layer as deep as $20 \mathrm{~cm}$ derived from dryland Susut Districts, Bangli Regency. Analysis of the characteristics of the soil, biochar and compost in the laboratory before the study is presented in Table 1 .

The experiment was conducted using a randomized block design (RBD) with nested test patterns (nested experiment), which nested dose factors for each type of fertilizer. Factors treatment consists of 3 types of fertilizers that biochar, compost, and Phonska with 4 levels dose and a control (no treatment) as a comparison. The composition of the treatment is: 0 ton/ha (without treatment), biochar 5 ton/ha, biochar 10 ton/ha, biochar 15 ton/ha, compost 10 tons/ha, compost 20 tons/ha, compost 30 tons/ha, phonska $150 \mathrm{~kg} / \mathrm{ha}$, phonska $300 \mathrm{~kg} / \mathrm{ha}$, phonska $450 \mathrm{~kg} / \mathrm{ha}$. Thus there are 9 treatment with 1 control, thus obtained 10 treatments in each replication. Each treatment was repeated 3 times so that the required 30 units of trial.

Planting corn seed that has been conducted in a poly bag filled with soil weighing $20 \mathrm{~kg}$. Biochar and compost treatment was given one time is one week before planting, while fertilizer Phonska given one week after planting with appropriate doses of treatment. Spacing between polybag 80 $\mathrm{cm}$ x $40 \mathrm{~cm}$. Parameters measured were plant height, leaf number, total leaf area, stem diameter, age out panicle (male flowers) and the ear hair (female flowers). Observations on plant height, leaf number, total leaf area and stem diameter of corn is done when the plants were $21,28,35,42,49$, and 56 days after planting (dap). Data were analyzed by analysis of variance followed by using the least significant difference test (LSD) and regression testing to determine the optimum dose treatment using Minitab 14 software.

\section{RESULTS AND DISCUSSION}

\section{A. Characteristics of Soil, Biochar Bamboo, and Compost}

Fertilizer demand for corn is closely related to soil nutrient status. Results of analysis of the soil in the study (Table 1) indicates that the electrical conductivity (EC) is relatively very low, $\mathrm{C}$-organic medium, the levels of $\mathrm{N}$-total is low, while the P-available high-status, while the $\mathrm{K}$ available generally considered to be very low, CEC was. With nutrient status Thus, it appears that the land where the study was not able to provide $\mathrm{N}$, and $\mathrm{K}$ are sufficient for the purposes of the corn plants to grow well, because it takes extra nutrients from the outside in the form of NPK fertilizer Phonska. Land area of research with sandy loam texture was also unable to provide electrical conductivity, organic $\mathrm{C}$, and CEC enough so that the necessary additional biochar and compost. Of soil conditions so, then after research showed that treatment doses of biochar, compost, and Phonska can significantly increase the growth of hybrid corn plants bisi-2 compared with no treatment (Table 2, 3).

TABLE I

CHARACTERISTICS ANALYSIS OF LAND, BIOCHAR, AND COMPOST [7]

\begin{tabular}{|c|c|c|c|c|c|}
\hline Type Analysis & Soil & \multicolumn{2}{|c|}{$\begin{array}{l}\text { Biochar } \\
\text { Bamboo }\end{array}$} & \multicolumn{2}{|c|}{$\begin{array}{c}\text { Compost } \\
\text { "Simantri"' }\end{array}$} \\
\hline 1. $\mathrm{pH} \mathrm{H}_{2} \mathrm{O}$ & 6,82 & 7,48 & $\mathrm{~N}$ & 7,35 & $\mathrm{~N}$ \\
\hline 2. $\mathrm{EC}(\mathrm{mmhos} / \mathrm{cm})$ & $0,43 \quad \mathrm{VR}$ & 0,77 & VR & 10,92 & $\mathrm{VH}$ \\
\hline 3. $\quad$-organic $(\%)$ & $2,69 \quad \mathrm{M}$ & 3,08 & $\mathrm{H}$ & 15,51 & $\mathrm{VH}$ \\
\hline 4. N-total $(\%)$ & 0,19 & 0,06 & VR & 0,82 & $\mathrm{VH}$ \\
\hline 5. $\mathrm{C} / \mathrm{N}$ & $14,16 \quad \mathrm{M}$ & 51,33 & VH & 18,91 & $\mathrm{H}$ \\
\hline 6. P-available (ppm) & 31,08 & 451,78 & $\mathrm{VH}$ & 650,14 & VH \\
\hline 7. K-available (ppm) & $31,75 \quad \mathrm{VR}$ & 36,07 & VR & 23,26 & VR \\
\hline 8. $\mathrm{Ca}(\mathrm{mg} / \mathrm{kg})$ & $1,64 \quad$ VR & 32,20 & $\mathrm{~L}$ & 9,28 & VR \\
\hline 9. $\mathrm{Mg}(\mathrm{mg} / \mathrm{kg})$ & $12,50 \quad \mathrm{M}$ & 15,88 & $\mathrm{M}$ & 15,16 & $\mathrm{M}$ \\
\hline 10. $\mathrm{Na}(\mathrm{mg} / \mathrm{kg})$ & 9,96 & 14,62 & VH & 15,26 & $\mathrm{VH}$ \\
\hline 11. CEC $(\mathrm{me} / 100 \mathrm{~g})$ & 16,14 & - & - & - & - \\
\hline 12. $\quad$ BS (\%) & 55,89 & - & - & - & - \\
\hline \multicolumn{6}{|l|}{ 13. Water content: } \\
\hline $\mathrm{AD}(\%)$ & 6,19 & 5,48 & - & 22,47 & - \\
\hline $\mathrm{FC}(\%)$ & 26,65 & - & - & - & - \\
\hline \multicolumn{6}{|l|}{ 14. Texture } \\
\hline Sand $(\%)$ & 60,30 & & & & \\
\hline Dust (\%) & $30,10 \quad$ SL & & & & \\
\hline Clay (\%) & 9,60 & & & & \\
\hline
\end{tabular}

Description: EC (Electrical conductivity), CEC (Cation Exchange Capacity), BS (base saturation), N (Neutral), VR (Very Low), L (Low), M (Moderate), H (Height), VH (Very high), AD (Air Dry), FC (Field Capacity), dan SL (Sandy Loam).

\section{B. Plant Height}

Results of analysis of variance showed that among types of fertilizer did not significantly affect plant height age of 56 dap, but the inter-dose treatment in this type of fertilizer very significant effect on plant height age of 56 dap. The average height of the plants for treatment of type and dose of fertilizer can be seen in Table 2. 
TABLE II

Average of Plant Heigh, Leaves Number and Total Leaf AREA AGED 56 DAP FOR TREATMENT AND DOSE OF FERTILIZER

\begin{tabular}{|c|c|c|c|}
\hline Treatment & $\begin{array}{c}\text { Plant } \\
\text { Height } \\
(\mathrm{cm}) \\
\end{array}$ & $\begin{array}{c}\text { Leaves } \\
\text { Number } \\
\text { (strand) }\end{array}$ & $\begin{array}{c}\text { Total } \\
\text { Leaf Area } \\
\left(\mathbf{d m}^{2}\right)\end{array}$ \\
\hline Type Fertilizer & & & \\
\hline Biochar & 230,67 a & $15,17 \mathrm{a}$ & $105,31 \mathrm{a}$ \\
\hline Compost & 233,92 a & $15,17 \mathrm{a}$ & $106,28 \mathrm{a}$ \\
\hline Phonska & $233,33 \mathrm{a}$ & $15,08 \mathrm{a}$ & $107,08 \mathrm{a}$ \\
\hline BNT 5\% & - & - & - \\
\hline Dose Biochar & & & \\
\hline$\overline{0 \text { ton } / \text { ha }}$ & $211,00 \mathrm{c}$ & $14,00 \mathrm{~b}$ & $89,34 \mathrm{~b}$ \\
\hline 5 ton/ha & $\begin{array}{c}220,33 \\
\text { bc }\end{array}$ & $14,67 \mathrm{~b}$ & $95,82 \mathrm{~b}$ \\
\hline 10 ton/ha & $256,67 \mathrm{a}$ & $16,00 \mathrm{a}$ & $119,97 \mathrm{a}$ \\
\hline 15 ton/ha & $234,67 \mathrm{~b}$ & $16,00 \mathrm{a}$ & $116,10 \mathrm{a}$ \\
\hline Dose Compost & & & \\
\hline 0 ton/ha & $211,00 \mathrm{~b}$ & $14,00 \mathrm{c}$ & $89,34 \mathrm{c}$ \\
\hline 10 ton/ha & $240,00 \mathrm{a}$ & $15,00 \mathrm{~b}$ & $105,33 \mathrm{~b}$ \\
\hline 20 ton/ha & $247,00 \mathrm{a}$ & $15,67 \mathrm{ab}$ & $117,80 \mathrm{a}$ \\
\hline 30 ton/ha & 237,67 a & $16,00 \mathrm{a}$ & $112,66 \mathrm{ab}$ \\
\hline Dose Phonska & & & \\
\hline $0 \mathrm{~kg} / \mathrm{ha}$ & $211,00 \mathrm{~b}$ & $14,00 \mathrm{~b}$ & $89,34 \mathrm{~b}$ \\
\hline $150 \mathrm{~kg} / \mathrm{ha}$ & $237,67 \mathrm{a}$ & $15,33 \mathrm{a}$ & $111,53 \mathrm{a}$ \\
\hline $300 \mathrm{~kg} / \mathrm{ha}$ & $245,67 \mathrm{a}$ & $15,67 \mathrm{a}$ & $114,72 \mathrm{a}$ \\
\hline $450 \mathrm{~kg} / \mathrm{ha}$ & $239,00 \mathrm{a}$ & $15,33 \mathrm{a}$ & $112,72 \mathrm{a}$ \\
\hline BNT 5\% & 18,72 & 0,80 & 11,96 \\
\hline Coefficient Diversity (\%) & 4,75 & 3,13 & 6,65 \\
\hline
\end{tabular}

Description: The same letter behind the average value in the same column, showed no significant difference in the level of LSD 5\%

From Table 2 it appears that at the age of 56 dap highest plant height was obtained at doses of biochar 10 ton/ha as high as $256.67 \mathrm{~cm}$ were significantly different with no treatment, 5 ton/ha, and 15 tons/ha respectively with a value of $211.00 \mathrm{~cm}, 220.33 \mathrm{~cm}$ and $234.67 \mathrm{~cm}$. Dosage of compost 20 tons/ha gave the highest plant height $247.00 \mathrm{~cm}$ were not significant to the treatment of 10 tons/ha and 30 ton/ha each with a value of $240.00 \mathrm{~cm}$ and $237.67 \mathrm{~cm}$, but significantly different from the untreated $211.00 \mathrm{~cm}$. While the dosage of phonska $300 \mathrm{~kg} / \mathrm{ha}$ gave the highest plant height $245.67 \mathrm{~cm}$ were not significant with the treatment of $150 \mathrm{~kg} / \mathrm{ha}$ and 450 $\mathrm{kg} / \mathrm{ha}$ each with a value of $237.67 \mathrm{~cm}$ and $239.00 \mathrm{~cm}$, but significantly different from the untreated $211.00 \mathrm{~cm}$. To determine the average growth of plant height age of 21,28 , $35,42,49$, and 56 days after planting can be seen in Figure 1.

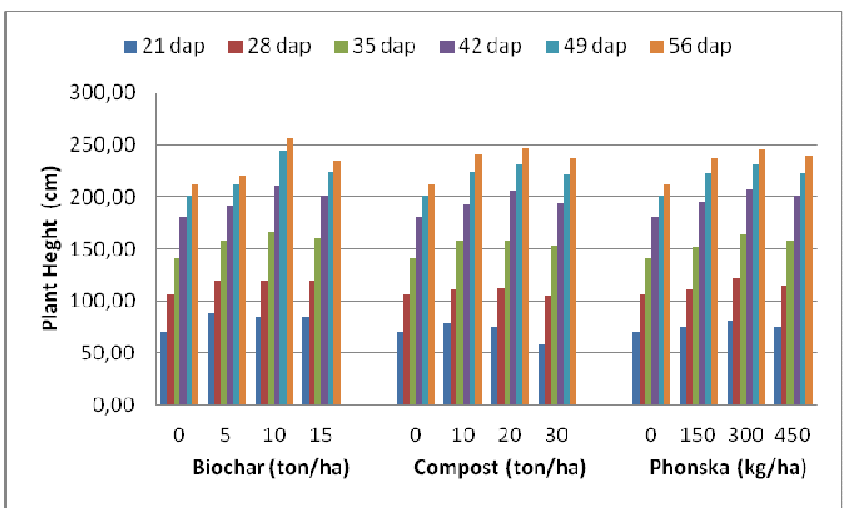

Fig 1. Relationship dosing of biochar, compost, and phonska to average height plant age $21,28,35,42,49$, and 56 dap
From the results of this study showed that treatment with a dose of 10 tonnes/ha biochar, 10 tonnes/ha of compost, and $150 \mathrm{~kg} / \mathrm{ha}$ phonska provide the highest value to the plant height, whereas the untreated fertilizer gave the lowest score to the plant height.

\section{Leaves Number}

Results of analysis of variance showed that the fertilizer did not significantly affect the number of leaves age of 56 dap, but the inter-dose treatment in this type of fertilizer very significant effect on the amount of leaf age 56 dap. The average number of leaves due to treatment type and dose of fertilizer can be seen in Table 2 .

From Table 2 it appears that at the age of 56 dap number of leaves, the highest obtained at doses of biochar 10 ton/ha and 15 ton/ha of 16 strands were significantly different with no treatment and 5 ton/ha respectively with value 14.00 and 14.67 strands. Dosage of compost 30 tons/ha gave the highest leaf number of different strands 16,00 unreal to the treatment of 20 tons/ha, but significantly different from the untreated 14.00 piece and a dose of 10 tonnes/ha 15 strands. phonska fertilizer dosage of $300 \mathrm{~kg} / \mathrm{ha}$ gave the highest leaf number of different strands 15.67 unreal with the treatment of $150 \mathrm{~kg} / \mathrm{ha}$ and $450 \mathrm{~kg} / \mathrm{ha}$ each with the same value, namely 15.33 strands, but significantly different with no treatment 14 strands.

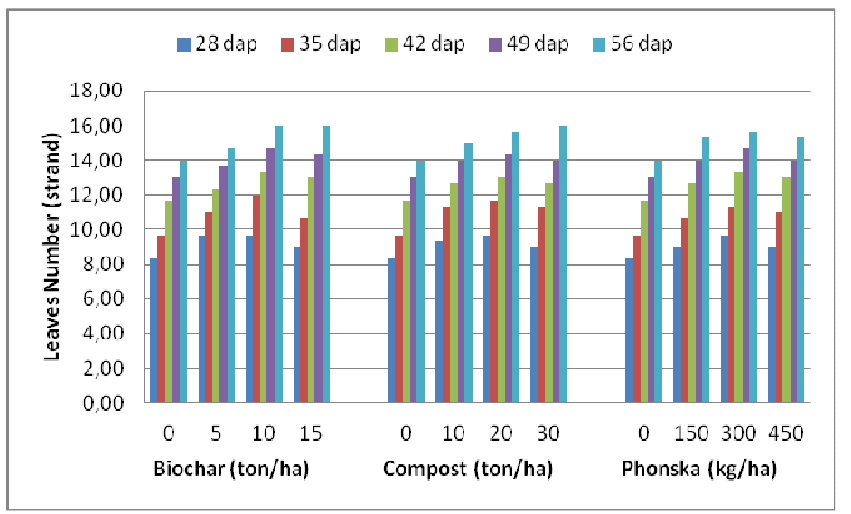

Fig 2. Relationship dosing biochar fertilizer, compost, and phonska to the average number of leaves of the plant ages $28,35,42,49$, and 56 dap

Based on the results obtained from this study showed that treatment with a dose of 10 tonnes/ha biochar bamboo, 2030 tonnes/ha of compost and $150 \mathrm{~kg} / \mathrm{ha}$ of fertilizer Phonska provide the highest value to the number of leaves, whereas the untreated fertilizer gave the lowest rating of the number of leaves. To determine the average number of leaves age of $28,35,42,49$, and 56 days after planting can be seen in Figure 2.

\section{Total Leaf Area}

Results of analysis of variance showed that the fertilizer did not significantly affect the total leaf area age 56 dap, but the inter-dose treatment in this type of fertilizer very significant effect on the total leaf area age 56 dap. The average total leaf area due to treatment type and dose of fertilizer can be seen in Table 2.

From Table 2 it appears that at age 56 dap highest total leaf area was obtained at doses of biochar 10 tonnes/ha as high as $119.97 \mathrm{dm}^{2}$ were not significant with 15 ton/ha 
amounted to $116.10 \mathrm{dm}^{2}$, but significantly different from the untreated and 5 ton/ha respectively with a value of 89.34 and $95.82 \mathrm{dm}^{2}$. Dosage of compost 20 tons/ha gave the highest total leaf area $117.80 \mathrm{dm}^{2}$ were not significant with 30 ton/ha amounted to $112.66 \mathrm{dm}^{2}$, but significantly different from the untreated and 10 ton/ha respectively 89.34 and $105.33 \mathrm{dm}^{2}$. Phonska dosage of $300 \mathrm{~kg} / \mathrm{ha}$ provide the highest total leaf area $114.72 \mathrm{dm}^{2}$, which is not significant to the treatment of $150 \mathrm{~kg} / \mathrm{ha}$ and $450 \mathrm{~kg} / \mathrm{ha}$ respectively 111.53 and $112,72 \mathrm{dm}^{2}$, but significantly different from the untreated $89.34 \mathrm{dm}^{2}$. The average total leaf area age 28, 35, 42, 49, and 56 dap can be seen in Figure 3.

From the above it can be seen that the treatment with a dose of 10 tonnes/ha biochar, 20 tonnes/ha of compost and $150 \mathrm{~kg} / \mathrm{ha}$ of fertilizer phonska provide the highest value total leaf area, whereas the untreated fertilizer gave the lowest score total leaf area 56 dap.

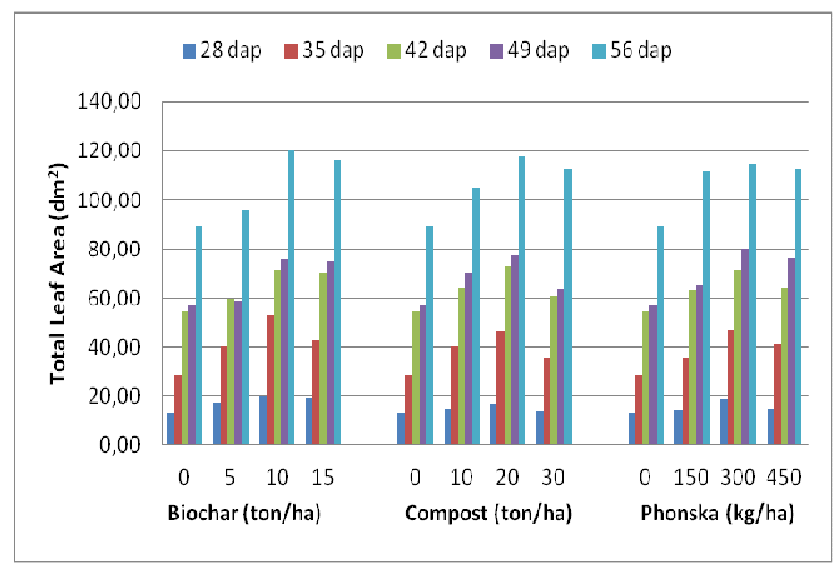

Fig 3. Relationship dosing biochar fertilizer, compost, and phonska to average total leaf area age $28,35,42,49$, and 56 dap

\section{E. Stem Diameter}

Results of analysis of variance showed that among types of fertilizers and between doses in the kind of fertilizer did not significantly affect the stem diameter. The average diameter of the stem because the treatment type and dose of fertilizer can be presented in Table 3.

Based on Table 3 shows there is a tendency that the treatment dose of 10 tonnes/ha of biochar, 30 tonnes/ha of compost and $450 \mathrm{~kg} / \mathrm{ha}$ of fertilizer phonska deliver the highest value to the diameter of the base of the stem, whereas the untreated fertilizer gives the lowest value of the diameter of the base of the stem.

\section{F. Age Exit Panicle}

Results of analysis of variance showed that the fertilizer did not significantly affect the life of out panicle, but the inter-dose treatment in this type of fertilizer significantly to very significantly to age out panicles. The average age of exit panicles because treatment type and dose of fertilizer can be seen in Table 3 .

Table 3 shows that age out panicle fastest biochar obtained at a dose of 10 tonnes/ha 49.67 dap significantly different with no treatment, but had no significant with and 5 tons/ha and 15 ton/ha respectively with a value of 50.00 and 50.33 dap. Dosage of compost 20 tons/ha provide the fastest panicle exit age are significantly different dap 49.67 with no treatment and 30 ton/ha respectively with a value of 52.67 and $52.00 \mathrm{dap}$, but did not differ significantly with 10 ton/ha amounted to 50.33 dap. While the dosage of fertilizer phonska $300 \mathrm{~kg} / \mathrm{ha}$ provide the fastest panicle exit age is 49.00 dap, which is significantly different from the untreated 52.67 dap, but did not differ significantly with the treatment of $150 \mathrm{~kg} / \mathrm{ha}$ and $450 \mathrm{~kg} / \mathrm{ha}$ each with a value of 50.67 and 49.33 dap. From the results of this study can be seen that with a dosage of 5-10 tonnes/ha biochar, 10-20 tonnes/ha of compost, and $150-300 \mathrm{~kg} / \mathrm{ha}$ of fertilizer phonska provide the quickest exit age panicle, whereas the untreated fertilizer gives the longest time discharge panicle.

TABLE III

ChARACTERISTICS ANALYSIS OF LAND, BIOCHAR, AND COMPOST [7]

\begin{tabular}{|l|c|c|c|}
\hline Treatment & $\begin{array}{c}\text { Stem } \\
\text { Diameter } \\
\text { (cm) }\end{array}$ & $\begin{array}{c}\text { Age Exit } \\
\text { Panicle } \\
\text { (dap) }\end{array}$ & $\begin{array}{c}\text { Age Hair } \\
\text { Out Cob } \\
\text { (dap) }\end{array}$ \\
\hline Type Fertilizer & $2,61 \mathrm{a}$ & $50,67 \mathrm{a}$ & $54,25 \mathrm{a}$ \\
Biochar & $2,65 \mathrm{a}$ & $51,17 \mathrm{a}$ & $54,67 \mathrm{a}$ \\
Compost & $2,64 \mathrm{a}$ & $50,42 \mathrm{a}$ & $54,25 \mathrm{a}$ \\
Phonska & - & - & - \\
BNT 5\% & & & \\
\hline Dose Biochar & $2,51 \mathrm{a}$ & $52,67 \mathrm{a}$ & $56,00 \mathrm{a}$ \\
0 ton/ha & $2,60 \mathrm{a}$ & $50,00 \mathrm{~b}$ & $54,00 \mathrm{~b}$ \\
5 ton/ha & $2,76 \mathrm{a}$ & $49,67 \mathrm{~b}$ & $53,67 \mathrm{~b}$ \\
10 ton/ha & $2,58 \mathrm{a}$ & $50,33 \mathrm{~b}$ & $53,33 \mathrm{~b}$ \\
15 ton/ha & & & \\
\hline Dose Compost & $2,51 \mathrm{a}$ & $52,67 \mathrm{a}$ & $56,00 \mathrm{a}$ \\
0 ton/ha & $2,68 \mathrm{a}$ & $50,33 \mathrm{bc}$ & $53,67 \mathrm{~b}$ \\
10 ton/ha & $2,69 \mathrm{a}$ & $49,67 \mathrm{c}$ & $53,67 \mathrm{~b}$ \\
20 ton/ha & $2,74 \mathrm{a}$ & $52,00 \mathrm{ab}$ & $55,33 \mathrm{ab}$ \\
30 ton/ha & & & \\
\hline Dose Phonska & $2,51 \mathrm{a}$ & $52,67 \mathrm{a}$ & $56,00 \mathrm{a}$ \\
$0 \mathrm{~kg} / \mathrm{ha}$ & $2,64 \mathrm{a}$ & $50,67 \mathrm{ab}$ & $55,00 \mathrm{a}$ \\
$150 \mathrm{~kg} / \mathrm{ha}$ & $2,69 \mathrm{a}$ & $49,00 \mathrm{~b}$ & $53,00 \mathrm{~b}$ \\
$300 \mathrm{~kg} / \mathrm{ha}$ & $2,72 \mathrm{a}$ & $49,33 \mathrm{~b}$ & $53,00 \mathrm{~b}$ \\
$450 \mathrm{~kg} /$ ha & - & 2,21 & 1,96 \\
\hline LSD 5\% & 4,50 & 2,57 & 2,13 \\
\hline Coefficient Diversity $(\%)$ & & \multicolumn{2}{|c}{} \\
\hline
\end{tabular}

Description: The same letter behind the average value in the same column, showed no significant difference in the level of LSD 5\%

\section{G. Age Hair $\mathrm{Out} \mathrm{Cob}$}

Results of analysis of variance showed that the fertilizer did not significantly affect the hair out when the cob, but the inter-dose treatment in this type of fertilizer to the very real significant effect on the way out hair cob. The average age of ear hair out because of treatment type and dose of fertilizer can be seen in Table 3.

Table 3 shows that when the hair out the fastest frigate biochar obtained at a dose of 15 tonnes/ha ie 53.33 dap were not significant with a 5 ton/ha and 10 ton/ha respectively with a value of 54,00 dap and 53.67 dap, but significantly different from the untreated 56.00 dap. Dosage of compost 10 and 20 ton/ha give the age of the hair out the fastest cob 53.67 dap were not significant with 30 ton/ha amounted to 55.33 dap, but significantly different from the untreated 52.67 dap. While the dosage of fertilizer phonska 300 and $450 \mathrm{~kg} / \mathrm{h}$ give the age of the hair out the fastest is 53.00 dap cob, which is significantly different from the untreated and 
the treatment of $150 \mathrm{~kg} / \mathrm{ha}$ respectively with dap value of 56.00 and 55.00. From the results of this study showed that treatment with a dose of 5 ton/ha biochar, 10 tonnes/ha compost and $300 \mathrm{~kg} / \mathrm{ha}$ of fertilizer phonska provide the quickest exit age cob hair, whereas the untreated fertilizer gives the longest time discharge cob hair.

\section{H. Effect of Biochar on Growth of Maize}

In observation of the growth of maize plants aged 56 days after planting showed that the highest plant height was obtained at doses of biochar 10 tonnes/ha of $256.67 \mathrm{~cm}$, or an increase of $21.64 \%$ when compared to the untreated $211.00 \mathrm{~cm}$ (Table 3). The regression analysis between high doses of biochar bamboo plants showed a quadratic relationship with the regression line equation: $\hat{Y}=206.7+$ $6.847 \mathrm{X}-0.3133 \mathrm{X}^{2}$, with a coefficient of determination $\left(\mathrm{R}^{2}\right)$ of $69.30 \%$ (Figure 4). From the results of the regression analysis obtained optimum dose biochar is 10.93 tonnes/ha with maximum plant height of $244.11 \mathrm{~cm}$. Based on the results of the regression analysis showed that plant height higher with the increasing doses of biochar to the optimum, then decreased when exceeding the optimum dose.

Entering the generative phase of the plants, the age of the hair out cobs can be achieved at a dose fastest 5 tonnes/ha of biochar at the age of 54.00 dap accelerated by $3.57 \%$ when compared to the untreated age 56 dap (Table 3). The regression analysis between doses of biochar bamboo to age out the cob hair showed a quadratic relationship with the regression line equation: $\hat{\mathrm{Y}}=55.92-0.4158 \mathrm{X}+0.0166 \mathrm{X}^{2}$, with a coefficient of determination $\left(\mathrm{R}^{2}\right)$ of $96.70 \%$ (Figure 5). From the results of the regression analysis obtained optimum dose biochar is 12.52 tonnes/ha with a minimum age of 53.32 cob hair out dap. Based on the results of the regression analysis showed that age out the cob hair faster with the increasing doses of biochar to the optimum, then aged out hair cob increased when exceeding the optimum dose.

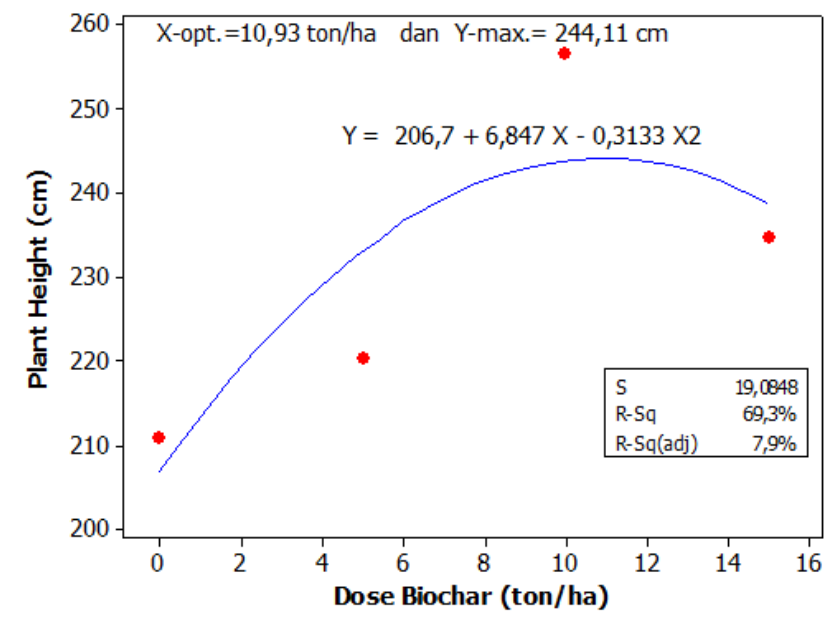

Fig 4. The relationship between doses of biochar with plant height

The high plant height and ear hair quickly age out at doses of biochar 5-10 tonnes/ha allegedly caused biochar as a soil able to improve soil fertility. The effect of biochar on soil fertility which can increase soil porosity, water holding capacity, CEC, BS, C-organic, nutrients and microbial activity in the soil.

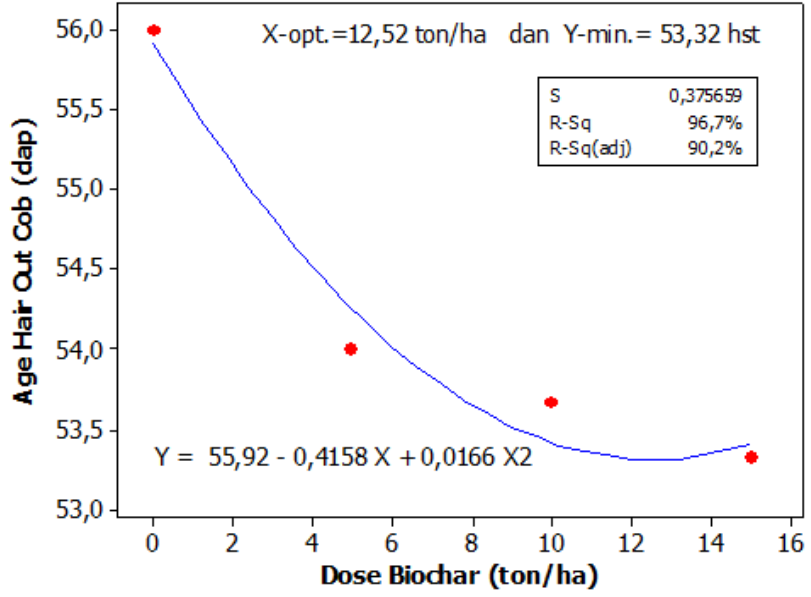

Fig 5. The relationship between doses of biochar to age out the cob hair

The properties of the soil is very important in encouraging early growth and stimulate vegetative growth of the plants, this condition causes the dosage of biochar 10 ton/ha provide plant height, number of leaves and total leaf area per plant was the highest. Increasing the number of leaves and total leaf area can increase the rate of plant growth and development, because the amount of light that can be in the interception of the photosynthesis process to form a dry material plant will increase. Assimilates are formed as a result of the process of photosynthesis will be used for the formation of new cells in the process of growth and development of vegetative organs of plants. This is consistent with results of previous studies, where the application of biochar from waste bamboo with a dose of 10 tonnes/ha showed a significant effect on the corn plant height [12].

\section{Effect of Compost on Growth of Maize}

In observation of the growth of maize plants aged 56 days after planting, the treatment dose of compost 20 tons/ha gave the highest plant height did not differ significantly with treatment of 10 ton/ha and 30 ton/ha, but significantly different from the untreated. This shows that the provision of compost 10 tons/ha and 30 tons/ha can provide the same high yield plants with the provision of 20 tons/ha. Plant height were obtained at a dose of compost 10 tons/ha is $240.00 \mathrm{~cm}$, or an increase of $13.74 \%$ when compared to the untreated $211.00 \mathrm{~cm}$ (Table 2). The regression analysis between high doses of compost to plant 56 dap showed a quadratic relationship with the regression line equation: $\hat{\mathrm{Y}}=$ $211.3+3.745 \mathrm{X}-0.09583 \mathrm{X}^{2}$, with a coefficient of determination $\left(\mathrm{R}^{2}\right)$ of $99.80 \%$ (Figure 6). From the results of the regression analysis obtained optimum dose of compost that is 19.54 tons/ha with maximum plant height of 247.89 $\mathrm{cm}$. Based on the results of the regression analysis showed that plant height higher with the increasing dose of compost to the optimum, then decreased when exceeding the optimum dose.

Entering the generative phase of the plants, the age of the hair out cobs can be achieved at the fastest dose of 10 tons/ha of compost each at the age of 54.00 dap accelerated by $4.16 \%$ when compared to the untreated 56 dap (Table 3 ). The regression analysis between the dose of compost to age 
out the cob hair showed a quadratic relationship with the regression line equation: $\hat{Y}=55.97-0.3193 \mathrm{X}+$ $0.009975 \mathrm{X}^{2}$, with a coefficient of determination $\left(\mathrm{R}^{2}\right)$ of $99.50 \%$ (Figure 7). From the results of the regression analysis obtained optimum dose of compost that is 16.01 tonnes/ha with a minimum age of $53.41 \mathrm{cob}$ hair out dap. Based on the results of the regression analysis showed that age out the cob hair faster with the increasing dose of compost to the optimum, then increased when exceeding the optimum dose.

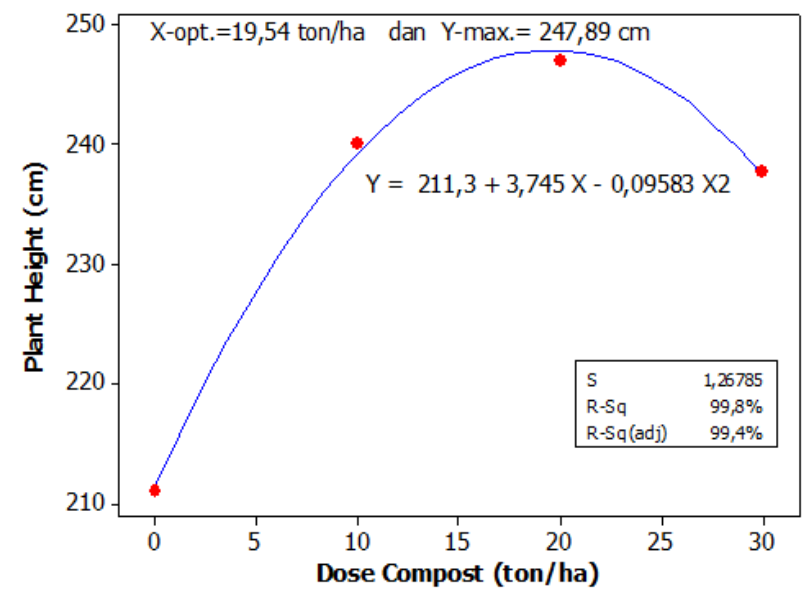

Fig 6. The relationship between the dose of compost with plant height

The high plant height and ear hair quickly age out at a dose of compost 10-20 tons/ha allegedly caused compost organic fertilizer which is able to improve soil fertility. Compost is the result of the decomposition of organic materials that can function to improve physical, chemical, and biological properties of soil, such as increased water retention capacity of the soil is greater, repair the structure and porosity of the soil, as a source of $\mathrm{N}$, increased $\mathrm{CEC}$, and substrates for soil microorganisms.

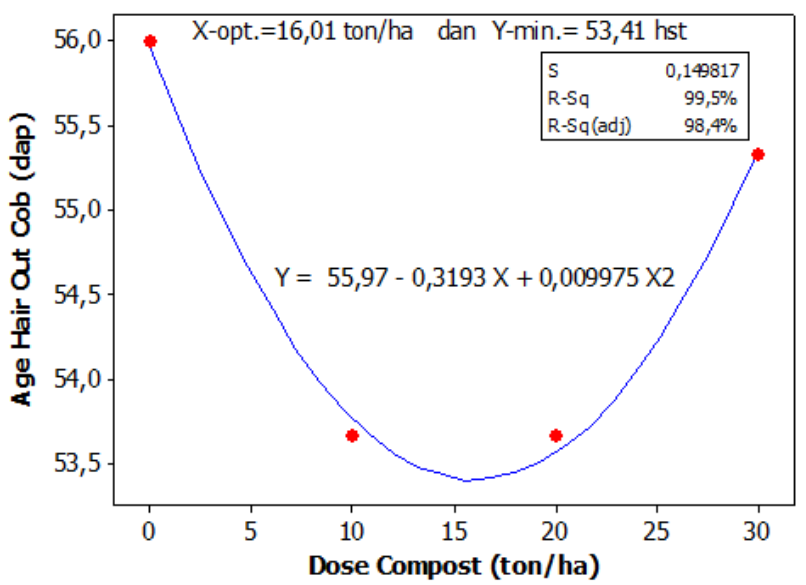

Fig 7. The relationship between the dose of compost to age out the cob hair

\section{J. Effect of Phonska on Growth of Maize}

Phonska fertilizer dosage of $300 \mathrm{~kg} / \mathrm{ha}$ gave the highest plant height did not differ significantly with the treatment of $150 \mathrm{~kg} / \mathrm{ha}$ and $450 \mathrm{~kg} / \mathrm{ha}$, but significantly different from the untreated. This shows that the administration of $150 \mathrm{~kg} / \mathrm{ha}$ phonska has been able to provide the same high yield plants with the provision of $300 \mathrm{~kg} / \mathrm{ha}$ phonska. Plant height obtained in phonska dose of $150 \mathrm{~kg} / \mathrm{ha}$ is $237.67 \mathrm{~cm}$, or an increase of $12.64 \%$ when compared to the untreated 211.00 $\mathrm{cm}$ (Table 2). The regression analysis between the high-dose phonska 56 dap plants showed a quadratic relationship with the regression line equation: $\hat{\mathrm{Y}}=211.2+0.228 \mathrm{X}-0.00037$ $\mathrm{X}^{2}$, with a coefficient of determination $\left(\mathrm{R}^{2}\right)$ of $99.90 \%$ (Figure 8). From the results of regression analysis found that the optimum dose phonska 308.11 tons/ha with maximum plant height of $246.32 \mathrm{~cm}$. Based on the results of the regression analysis showed that plant height higher with the increasing dose phonska to optimum, then decreased when exceeding the optimum dose.

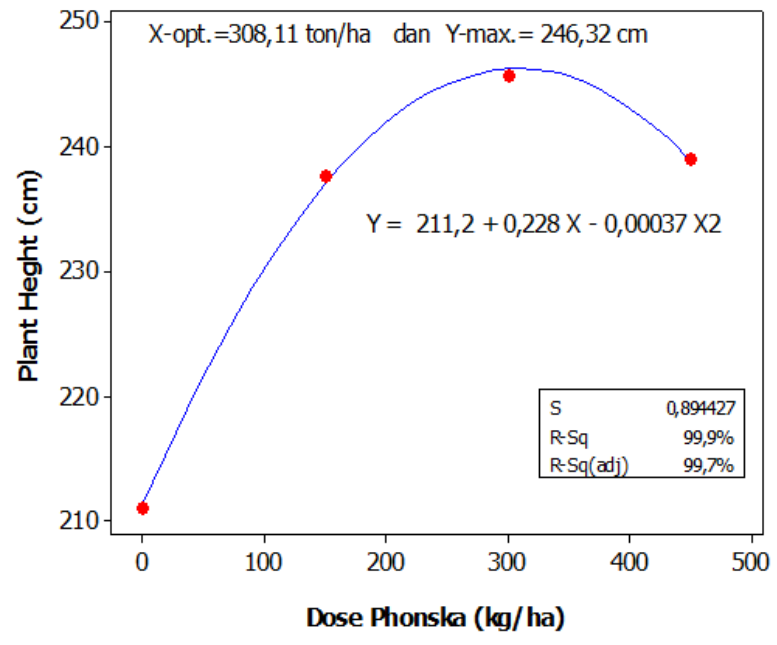

Fig 8 . The relationship between doses of phonska with plant heigh

Entering the generative phase of the plants, the age of the hair out cobs (female flowers) fastest achieved at a dose of $300 \mathrm{~kg} / \mathrm{ha}$ phonska accelerated by $3.57 \%$ when compared to the untreated 56 dap (Table 3).

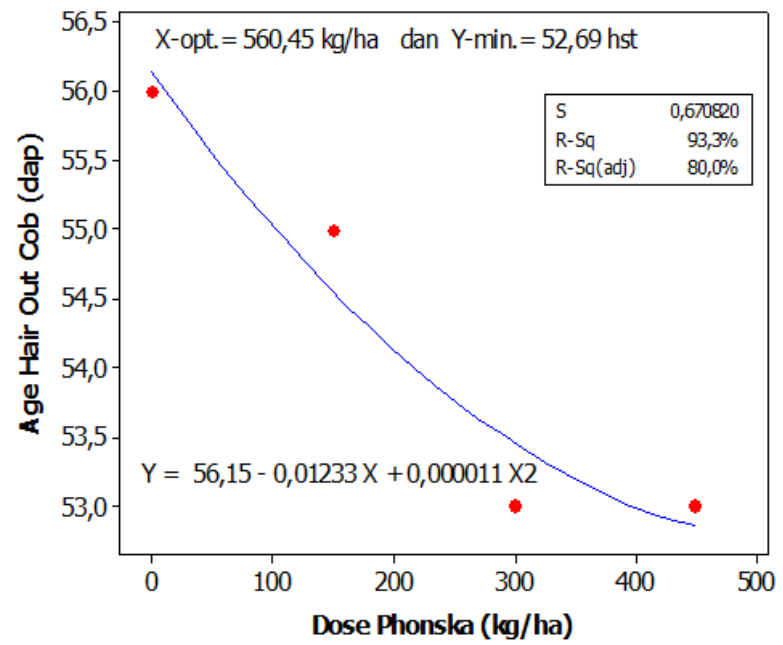

Fig 9. The relationship between dose phonska to age out the cob hair

The regression analysis between phonska dose to age out the cob hair showed a quadratic relationship with the regression line equation: $\hat{Y}=56.15-0.01233 X+0.000011$ 
$\mathrm{X}^{2}$, with a coefficient of determination $\left(\mathrm{R}^{2}\right)$ of $99.30 \%$ (Figure 9). From the results of regression analysis found that the optimum dose phonska $560.45 \mathrm{~kg} / \mathrm{ha}$ with a minimum age of 52.69 cob hair out dap. Based on the results of the regression analysis showed that age out the cob hair faster with the increasing dose phonska to optimum, then increased when exceeding the optimum dose.

The high plant height and ear hair quickly age out at a dose of fertilizer phonska $150-300 \mathrm{~kg} / \mathrm{ha}$ of fertilizer allegedly caused phonska which is able to provide the inorganic fertilizer NPK nutrients for the growth of corn plants. NPK fertilizer phonska also known as compound fertilizer because it contains nutrients main more than 2 types, the nutrient content of $\mathrm{N}(15 \%)$ in the form of $\mathrm{NH}_{3}, \mathrm{P}$ $(15 \%)$ in the form of $\mathrm{P}_{2} \mathrm{O}_{5}$ and $\mathrm{K}(15 \%)$ in the form $\left(\mathrm{K}_{2} \mathrm{O}\right)$, The element phosphorus (P), which plays an important role in the transfer of energy in the plant cells, promote root development and early conception, strengthens the stem so it does not easily fall, and increased $\mathrm{N}$ uptake in early growth. The element potassium (K) is also very instrumental in the growth of plants to stimulate translocation of carbohydrates from leaves to plant organs [1].

\section{CONCLUSIONS}

Treatment type of fertilizer showed no significant effect on all the variables observed, whereas treatment doses of biochar, compost, and phonska give real effect to very real to all the variables observed except for stem diameter that is not significant. Treatment of doses of 5-10 tonnes/ha biochar, 10-20 tonnes/ha compost, and 150-300 kg/ha phonska provide the highest growth of corn plants.

From the results of the regression analysis obtained optimum doses of biochar bamboo 10.93 tonnes/ha with maximum plant height of $244.11 \mathrm{~cm}$, the optimum dose of compost 19.54 tonnes/ha with maximum plant height of $247.89 \mathrm{~cm}$, and the optimum dose phonska $308.11 \mathrm{~kg} / \mathrm{ha}$ with a plant height of $246.32 \mathrm{~cm}$.

\section{REFERENCES}

[1] Aguslina, L. 2004. Dasar Nutrisi Tanaman. PT. Rineka Cipta. Jakarta.

[2] Atkinson, C.J., Fitzgerald, J.D., Hipps, N.A. 2010. Potential mechanisms for achieving agricultural benefits from biochar application to temperate soils: a review. Plant and Soil, 337: 1-18.

[3] Badan Penelitian Pengembangan Pertanian, 2012. Pembenah Tanah Biochar. Balai Penelitian Tanah. Kementerian Pertanian Republik Indonesia. [cited 2012 Des. 11]. URL: http://puslitklaten.wordpress.com/-tanah-biochar.

[4] BPS Bali, 2012. Bali Dalam Angka. Badan Pusat Statistik Prov. Bali.

[5] BPS, 2013. Produksi Padi, Jagung, dan Kedelai. Berita Resmi Statistik, No.45/07/Th.XVI.

[6] IBI, 2012. What is Biochar?. International Biochar Initiative. www.biochar-international. Org

[7] Laboratorium Tanah Fakultas Pertanian Universitas Udayana, 2015. Hasil analisis karakteristik tanah, biochar, dan kompos. Universitas Udayana, Denpasar.

[8] Glaser, B. 2001. The terra preta phenomenon: A model for sustainable agriculture in the humic tropic. Die Naturwissenschaften 88: $37-41$.

[9] Glaser, B, Lehmann, J., Zech, W. 2002. Ameliorating physical and chemical properties of highly weathered soils in the tropics with charcoal - a review. Biol Fertil Soils 35:219-230.

[10] Nurida, N. L., dan Rachman, A. 2011. Alternatif pemulihan lahan kering masam terdegradasi dengan formula pembenah tanah biochar di Typic Kanhapludults Lampung. Badan Litbang Pertanian, Balai Penelitian Tanah: 639-648

[11] Santoso, B., W. Mushollaeni, dan N. Hidayat, 2006. Tortilla. Trubus Agrisarana. Surabaya.

[12] Situmeang, Y.P. dan Sudewa, K.A. 2013. Respon pertumbuhan vegetatif tanaman jagung pada aplikasi biochar limbah bambu. Prosiding Seminar Nasional. Fakultas Pertanian Universitas Warmadewa. Denpasar. 